\title{
The divergent approaches of English and South African courts, when considering actuarial expert testimony in the matter of an award for damages for future loss of earnings after a damage-causing event
}

\author{
H.L.M. du Plessis* \\ Department of Insurance and Actuarial Science, University of Pretoria, South Africa
}

\begin{abstract}
This paper analyses the driving forces behind the willingness of South African courts to hear actuarial expert testimony in even the most simple of cases, in contrast to the more circumspect approach of the English courts, when assessing the damages arising out of future loss of earnings following a damage-causing incident. The analysis may well add insight to members of other professions and scientific communities that provide expert testimony to the courts. It is argued that English substantive law of damages and those influenced by its application have something to gain from a consideration of the approach in South Africa.
\end{abstract}

\section{Keywords}

Quantum of damages; future pecuniary loss; expert actuarial evidence; expert testimony; expert evidence; damages for future loss of earnings; damages for future pecuniary losses; multipliermultiplicand method

\section{Introduction}

The purpose of this paper is to trace the origins of the divergent approaches of English and South African courts, when it comes to the consideration of actuarial expert testimony regarding a loss of future earnings.

The analysis is performed within the boundaries of a particular instance of the quantification of damages, as set out in Section 6. The branches of English and South African law relevant to this particular instance are examined. The respective substantive legal rules are then reduced to fit into the structure of a formal (or logic, or mathematical) system. This allows the distillation of the essence of the divergence in approach in the two jurisdictions.

*Correspondence to: H.L.M. du Plessis, Department of Insurance and Actuarial Science, University of Pretoria, Lynnwood Road, Pretoria, 0002, South Africa. Tel: +(127)12 420 4072. Fax: +(127)12 362 5273. E-mail: rinus.duplessis@up.ac.za 
The findings are reported for the benefit of an actuarial audience that might be either practising or have an academic interest in this particular field that intersects law and actuarial science.

\section{Contextualisation}

Somewhere around 1886 in the Eastern Cape, South Africa, counsel for the plaintiffs in Clair v Port Elizabeth Harbour Board and Kennedy $v$ Port Elizabeth Harbour Board ${ }^{1}$ argued that the evidence of actuaries afforded a good basis as to the measure of damages, citing a number of authorities to support this ascertainment. The learned judge appears to have agreed, as he based his award for damages to a large extent on annuity values derived from the 'Carlisle' and 'Northampton' tables, these tables being well known to nineteenth century actuaries.

Over time South African courts have increasingly relied on actuarial evidence (Howroyd \& Howroyd, 1958:65; Milburn-Pyle \& van der Linde, 1974; Koch, 1983). In the experience of the author, South African actuaries are commonly called by the courts to give expert testimony in cases involving the assessment of quantum of damages in lieu of future loss of earnings. This sometimes happens in even the most simple of cases.

In contrast, authors have commented on the historical reluctance of the English courts to rely on actuarial evidence. Refer, for example, to Street (1962); Prevett (1968); Owen \& Shier (1986) and Burrows (1987).

In 1984 an Inter-Professional Working Party consisting of actuaries and lawyers released a series of actuarial tables known as the Ogden Tables. These tables are published by the UK Government Actuary's Department and rely on actuarial principles for their construction. ${ }^{2}$ Increasingly these tables gained general acceptance by the English courts. The Evidence Act 1995 made it clear that the Ogden Tables may be admitted into evidence. The widespread use of the Ogden Tables is an indication of the English legal fraternity's acceptance of the authority of the actuarial principles underlying the tables, though not necessarily of the need of actuarial expert testimony.

Hodgkinson \& James (2007:467-470) trace the history of actuarial evidence in the English courts over the past few decades. They report of a long war waged in the 1970s and 1980s to convince the courts to allow actuarial evidence. Prevett (1968:295) remarks that until then the help of an actuary was sought in exceptional cases only. Some detail of various battles of this war can be gleaned from Prevett (1968) and Prevett (1972).

It would appear that the war is not over yet. Daykin (2009) suggests that the current English approach is not sensible in damage cases where the compensation is likely to be large, and proper actuarial advice should be sought under such circumstances.

It is hoped that this paper will add a few arrows to the quivers of English actuaries who wish to offer their professional opinions in the English courtrooms for the benefit of the public at large.

1 (1886) 5 EDC 311.

2 The tables are regularly updated to reflect recent statistics and research results. The sixth edition has appeared in 2007 and is available from the website of the Government Actuary's Department. It takes into consideration some interesting research by Butt et al. (2008). 


\section{The question of a surprising divergence}

The English courts are still reluctant to admit the testimony of actuaries, as reported by Hodgkinson \& James (2007:467-8). South African courts however, readily admit and frequently insist on actuarial testimony.

Erasmus (1975) has analysed the history of the South African law of damages, and concluded that the quantum of damages is established primarily by application of rules and concepts found in English law.

South African law of evidence is firmly rooted in its English parent. In fact, the Civil Proceedings Evidence Act 25 of 1965 has set South African common law of evidence as the English law of evidence as it stood on 30 May 1961, the day before South Africa became a republic.

Thus, the divergence in the approaches of the South African and English courts towards actuarial expert testimony is somewhat surprising. This, then, is the research problem.

Contrary to actuarial intuition, the problem is not solved by looking at it from an actuarial perspective. The answer lies primarily within the field of law, particularly the law of damages and the law of evidence, and the consequences of the operation and interaction of these branches of law, in circumstances where actuaries and other professionals maintain that their opinions are of an expert nature (as understood in legal parlance) for the benefit of the courts.

The author being a South African practitioner, the reader should appreciate that the literature considered will be biased towards South African law. However, the law of England and the law of South Africa are near identical as far as the procedural aspects of law in context of this research are concerned. This should therefore not invalidate the analysis.

\section{Outline of paper}

Sections 5 to 8 sketch the environment within which this research is conducted, for the benefit of an actuarial audience. Section 9 states South African rules of assessment of damages. Sections 10 to 12 outline the procedures followed by English and South African courts in the process to assess damages. Sections 13 to 15 examine the English law for the establishment of damages. It then contrasts the English approach with the South African approach, in particular relating to the practice of admitting actuarial expert testimony. A summary of the author's findings appears in Section 16. The author's conclusions are stated in Section 17.

\section{Terminology}

A review of the literature shows that scholars of law use a variety of terms when referring to the same concept. Thus, for the purpose of an actuarial audience, some elements of terminology need to be introduced first in order to limit confusion.

\subsection{Damage and Damages}

The Concise Oxford Dictionary defines 'damage' as 'harm or injury impairing the value or usefulness of something, or the health or normal function of a person'. The same source defines 
'damages' as 'a sum of money claimed or awarded in compensation for a loss or an injury'. Authors such as Boberg (1984), Koch (1993) and Visser \& Potgieter (2003b) seem to have similar concepts in mind, when referring to damage and damages. However, their definitions are couched in more pure legal-technical terms. For the purpose of an actuarial audience the dictionary definitions should suffice, though.

Koch (1993:47-48) calls 'damage' an 'intuitive concept' that is determined by economic and scientific considerations. Damage as a concept is not restricted to the world of law. It evolves together with advances in economics and the sciences, and is widely understood on an intuitive level.

In contrast, 'damages' is a strictly legal term for monetary compensation that becomes the focus of litigation and possibly a monetary award by the court, in lieu of the damage suffered by the plaintiff.

\subsection{Patrimony}

The usual meaning of patrimony is an inheritance. The legal meaning thereof is different, and not well known outside legal circles. The question as to what to include in a definition of this concept is contentious even among legal authors themselves. ${ }^{3}$ The lack of agreement would appear not to be a hindrance to the effective operation of the South African legal system. ${ }^{4}$

However, for the purpose of this analysis a definition is needed. The following definition is suggested. One's patrimony (or estate) can be viewed as the collection of all of one's rights and duties, including expectation of such rights and duties. The rights and duties must be capable of monetary expression, to be counted towards patrimony. It excludes personal rights such as health of mind or body.

\subsection{Loss}

In the field covered by this paper, 'damage' is frequently referred to as 'loss', and thus the two terms are used interchangeably.

\subsection{Prospective Loss}

Visser \& Potgieter (2003b:22) defines it as 'damage... which will, with a sufficient degree of probability or possibility, materialise after the time of assessment of damage on account of an earlier damage-causing event.'

\subsection{Quantum of Damages}

This seems to be the preferred term in legal circles, of the measure of damages.

\section{Scope of consideration}

In the interest of academic rigour, and taking into consideration the fragmented nature of the common law operating in conjunction with the rigidity of a formal logic set out below, the environment of the analysis has to be carefully delineated. If this is not done, then the analysis, summary and conclusions may be invalidated.

${ }^{3}$ See, for instance, Visser \& Potgieter (2003a) footnotes at 54-55, Visser \& Potgieter (2003b) at 19 and Van der Walt \& Midgley (2005) at 46.

${ }^{4}$ See Visser \& Potgieter (2003a) at 48. 
In what follows, it will be assumed that the damage and damages under consideration will satisfy the following limiting criteria:

- the damage relates only to the period following the date of assessment, i.e. it is prospective, (i.e. we are ignoring any losses between the date of commission of the wrong and the date of assessment, on the presumption that such losses have been agreed upon and are not part of the dispute);

- the plaintiff had no promotional prospects over the balance of his career;

- there is only one plaintiff and only one defendant;

- the plaintiff has zero residual earnings capacity;

- it has already been established that the defendant is liable;

- it has already been established that there is no contributory negligence on the side of the plaintiff;

- the matter has reached such a stage that evidence in open court is now being considered, in order to establish the quantum of damages;

- it has already been established that the damages will be settled in the form of a lump sum, not an annuity $^{5}$; and

- likely compensation is so large that the matter is heard in the High Court.

\section{The doctrine of precedent}

It should be kept in mind that both England and South Africa are common law jurisdictions. They do not have comprehensive purpose-made statutory laws that govern the assessment of quantum of damages (although a sprinkling of statutory law has been added over the years). Instead one has to turn to judge-made rules of law as contained in the (either reported or unreported) judgments of the higher courts. This approach is commonly referred to as the 'doctrine of precedent'. This doctrine dictates that there is 'a general duty of judges to follow the legal rulings in previous judicial decisions' (Hahlo \& Kahn, 1973:214). Thus if in a particular case the material facts are the same as those that existed at the hearing of a previous case then the previous ruling must be followed. A hierarchy of courts exists and the higher up the hierarchy the stronger the authority of such court's pronouncements. In particular, a court of appeal carries more authority than the court of first instance, and may override any rules made by the court of first instance.

In what follows, these rules are loosely referred to as 'general' rules of law.

This system is commonly found in the anglophone jurisdictions, such as the United States of America, Australia, Scotland and parts of Canada (besides the two jurisdictions under consideration ${ }^{6}$ ). Continental Europe generally uses a substantially different system.

As a result of the operation of a common law system, the quantum rules will differ from one jurisdiction to the next.

It would appear from a study of the writings of legal scholars that the extent of generally recognised South African rules of law for the assessment of damages is limited. Koch (1993:39) expresses

\footnotetext{
5 It may be argued that compensation by periodical payments is an inherently superior method to match the cash flows of lost earnings. That, however, is not the focus of this paper.

${ }^{6}$ Wales is considered to be part of England's jurisdiction.
} 
surprise at this lack of detailed legal rules, given that there have been so many reported court judgments that address this issue. In fact, South African courts seem to shy away from laying down hard-and-fast rules.

On the other hand, the English courts do not share this reluctance.

It is suggested that this difference in approach lies at the root of the difference in treatment of actuarial expert testimony by South African and English courts.

\section{Formal systems: law and logic}

Part of the backdrop of this paper concerns the structure of a formal (or logic, or mathematical) system. In terms of such a system, there are definitions and a list of well-formed statements called axioms that are accepted without proof. Building on the axioms one can create valid (but not necessarily true) statements called theorems, obtained by applying logical deduction.

Extending this to the study of law, the formalist view of law holds that law can be treated as a science with its own set of fundamental rules resembling a formal system's axioms and theorems. There are some doubts among legal scholars and practitioners as to the validity of the formalist view, and it is by no means universally accepted. It is commonly argued that law as a discipline does not operate within a vacuum and some real-life practicality needs to be injected. However, for the purpose of this paper it is assumed that the formalist view of law is valid. The quest is then to establish a set of axioms the courts in South Africa and England assume and use without proof, when establishing the quantum of damages.

Due to the fragmented nature of the common law system, it is to be expected that the axioms in the two jurisdictions are unlikely to be the same. This is indeed the case.

\section{Contextualised axiomatic quantum rules in South African law}

Regarding the quantification of damages within the narrow environment sketched in Section 6, it is suggested that South African common law contains only two rules that can be considered to be fundamental in an axiomatic sense.

\subsection{Rule 1: The Difference Rule}

This rule was introduced to South African law by Judge of Appeal Innes in the Union Government $v$ Warneke case $^{7}$, and is widely recognised as the prevailing view in South African law (Reyneke 1976:27). The essence of this rule is that the loss is the difference between the plaintiff's estate (or patrimony) after the damage-causing event, and what it would have been had the event not taken place. It then becomes a question related to the concept commonly known as human capital, which has been addressed (albeit in ancient formulation) in Adam Smith's The Wealth of Nations $(1776)^{8}$. The trier of fact has to evaluate the diminution of human capital. Within the scope of the research

${ }^{7}$ Union Government v Warneke $1911 \mathrm{AD} 657$ at 665.

${ }^{8}$ Interestingly, Smith referred to patrimony in the same context as modern-day legal scholars, see Spengler (1977:33). 
problem, the evaluation of the loss can then be formally described as a stochastic processes problem, with all kinds of imponderables relating to the future turn of events having an influence on the 'fair value' of human capital.

\subsection{Rule 2: Damages is a Fact}

The quantum of damages is a fact that has to be determined by reference to the specific circumstances of the case. There is no standard formula to calculate it. This view has been confirmed as the South African legal position in De Jager $v$ Grunder $^{9}$, and later reaffirmed in Erasmus $v$ Davis ${ }^{10}$ where it was stated:

Whether a plaintiff has indeed suffered damages and the quantum thereof are questions of fact which must be determined according to the circumstances of the particular case.

The statement of rule 2 might seem quite obvious and of no practical value. This, however, is not the case.

The legal procedure for the establishment of a fact is very specific, and would seem to be a driver for the tendency of South African courts to rely on actuarial testimony. Also, as the facts vary from case to case, previous awards of damages do not offer much guidance to the trier of fact. In each case, all evidence, whether of expert or non-expert nature, has to be considered ab initio.

Surprisingly, it appears as if no other universally applicable rules besides rule 1 and 2 exist that can assist the trier of fact in making the determination regarding the quantum of damages.

A number of legal authors have commented on the reluctance of South African courts to lay down further general rules of quantum. Refer, for instance, to Koch (1984:10), Koch (1993:39), Visser \& Potgieter (2003a:493) and the preface to Van der Walt \& Midgley (2005). Yet, there must have been many opportunities to do so. In a number of cases, the court of first instance attempted to set such general rules but these have repeatedly been overturned on appeal. It is suggested that the only reason why no more fundamental rules have been made, is that no such additional rules currently exist within the framework of South African common law for assessment of quantum of damages. In the words of Judge of Appeal Van Blerk in Erasmus $v$ Davis ${ }^{11}$, 'the quantification of damages is not done according to formulae or hackneyed practice rules' [author's translation]. This is not to say that the existence of additional fundamental rules may not emerge in future. That is the nature of any science.

Future pecuniary damages, although a fact, cannot be measured with ease. One cannot but have sympathy for the trier of fact, looking into the future armed with a universe of tools consisting of only two broadly-stated rules.

The difficulty faced by the court has been well summarised in Goodall $v$ President Insurance ${ }^{12}$ where the judge commented that 'The art or science of foretelling... is not numbered among the qualifications for judicial office'.

9 De Jager $v$ Gruder 19641 SA 446 (A) at 451.

10 Erasmus $v$ Davis 1969 (2) SA 1 (A) at 17.

11 Ibid. at 5

12 Goodall v President Insurance Co Ltd 1978 (1) SA 389 (W) at 392-3 
It is therefore no surprise that South African courts regularly allow actuarial expert testimony regarding future pecuniary damage.

The rule of precedent applies to the reception of opinion [expert] testimony (Zeffert et al., 2003:300). The South African lawmakers have however not elevated the reception of actuarial expert testimony on the subject of future pecuniary damages to the level of a common law rule. The lawmakers have, on various occasions though, remarked on the value of actuarial testimony. ${ }^{13}$

\section{Establishing the quantum of damages}

The physical court procedure used to establish the quantum of damages rests heavily on two branches of law, namely the law of evidence and procedural law. There are two major international systems upon which the law of evidence and procedural law can rest (Schmidt \& Rademeyer 2000:12). The AngloAmerican approach, commonly used in anglophone jurisdictions, is adversarial. The Continental approach, commonly used in continental Europe, is inquisitorial. The major difference in approach lies in firstly, the involvement of the judicial officer such as the judge or magistrate, and secondly the admissibility rules. In terms of the Anglo-American approach, the presentation of evidence to the trier of fact is tightly regulated, and only 'admissible' evidence is allowed to be heard. The judicial officer plays a passive role, and decides what the facts are after listening to each side presenting its case. In nature the format of the proceedings is similar to a boxing match with the referee not getting involved in the fight. The Continental approach allows the judicial officer to be actively involved in the process, asking most of the questions and becoming involved in the dispute. Also, evidence is seldom excluded and there is much less focus on the 'admissibility' or otherwise of evidence.

English and South African law of evidence and procedural law follow the Anglo-American approach.

\section{Procedural law}

Procedural law sets out the procedure that the court has to follow when it goes about its business of (amongst others) establishing a fact such as the quantum of damages.

In the case under consideration, the plaintiff and defendant are not in agreement as to the quantum of damages. The trier of fact now considers evidence including testimony, in order to make an assessment of the damages. An outline of the procedure is given in appendix A.

\section{Law of evidence}

The law of evidence regulates the manner in which facts are proven in court. Schmidt \& Rademeyer (2003) provides a thorough treatment of the law of evidence.

A fact is established after consideration of evidence. 'Evidence' has a particular meaning at law. Carstens (2001:50) defines evidence as 'the testimony of witnesses and the production of documents and other exhibits, which can be used for the purpose of proof in legal proceedings.' A 'witness' is 'a person who gives formal or sworn evidence at a hearing'.

${ }^{13}$ For example, Arendse v Maher 1936 TPD at 162 and Southern Insurance Association Ltd $v$ Bailey NO 1984 (1) SA 98 (A) at 99, 105, 106 and 114. The latter case has probably done more than any other to cause South African courts to rely on actuarial testimony. 
'Testimony' in a legal sense is a subset of evidence. It is a solemn statement or declaration of fact. It may be oral or written, but under oath in either case. A false oath is perjury, which constitutes a criminal offence.

When giving testimony in court, witnesses may only testify about things that they have perceived with their senses, e.g. what they have seen. Witnesses are not allowed to offer their opinions. An opinion as such is deemed 'inadmissible evidence' and may not be presented to the court, subject to certain exceptions.

Meintjes-Van der Walt (2001) analysed one important exception to this rule - that of expert opinion testimony. Such testimony is admissible provided it is sufficiently relevant. It is relevant if, according to Meintjes-Van der Walt (2001:238), 'the expert by reason of special knowledge or skill, is better qualified to draw an inference than the trier of fact', the trier of fact being the court. However, relevance by itself is not sufficient for the testimony to be admissible. The opinion of the expert must give appreciable assistance to the trier of fact, implying that the evidence must pass a cost-benefits test. It is for the court to rule on the admissibility or inadmissibility of the testimony. When a matter falls within the common knowledge of the trier of fact then the opinion of an expert witness as such is superfluous and should not be admitted as evidence. However, from the analysis of Meintjes-Van der Walt (op. cit. at 244) it appears as if South African courts are quite lenient in allowing expert opinion testimony. The practice seems to be to readily admit testimony that purports to be of an expert nature, and then to leave it to the trier of fact to determine the level of reliance to place on the testimony, only after the testimony has been considered. Thus the hurdle for admissibility seems to be low and the hurdle for reliance is higher. When the hurdle for reliance has not been cleared, the trier of fact will attach little value to the testimony.

\section{Contextualised axiomatic quantum rules in English law}

Koch (1993) compares the laws of damages assessment in South African and English law. It would appear that the English lawmakers have been more enthusiastic in devising general rules of law (in the sense of axioms) to assist in the assessment of damages.

Given this enthusiasm, it is to be expected that the rules will differ according to the type of damage sustained. Hence it becomes necessary to delineate the environment carefully, as in Section 6 .

\subsection{English Rule 1: Restitio In Integrum}

Street (1962:3) sets out this rule by quoting from Lord Blackburn ${ }^{14}$ :

... where any injury is to be compensated by damages, in settling the sum of money to be given for reparation of damages you should as nearly as possible get at that sum of money which will put the party who has been injured, or who has suffered, in the same position as he would have been in if he had not sustained the wrong for which he is now getting his compensation or reparation.

14 Livingstone v. Rawyards Coal Co. (1880) 5 App.Cas. 25 at 39. 
Street (op. cit.) then also concludes that the English courts accept this rule even if the loss cannot be calculated precisely, as it would be in the case of future pecuniary loss. What happens in practice is that the court makes a broad estimate based on the facts proven after consideration of evidence and the court's perception of relevant probabilities (Exall 2004:78).

\subsection{English Rule 2: Use the Multiplier-Multiplicand Method}

First establish the annual pecuniary loss (the so-called 'multiplicand') on the basis of the evidence. The multiplicand may be adjusted for various subjective 'contingencies' e.g. loss of future promotion. Then establish a 'multiplier' (or commutation factor, or annuity value, which are the more common actuarial terms). The multiplier may also allow for subjective 'contingencies' such as the possibility that the plaintiff may have become unemployed irrespective of the injury. Multiply the two together. Arrive at a final figure. For an exposition of the method, see for example Exall, 2004:78-79; Holding, 1997:144-165; Burrows, 1987:174-176 and Koch, 1984:48-50.

In nature this is a simple deterministic process of arithmetic, subject to some judgment that falls within the qualifications of the trier of fact.

\subsection{English Rule 3: Use the "Ogden" Tables}

The House of Lords, England's highest court of appeal at that stage, approved of the use of the Government Actuary's Department's 'Ogden' tables, in 1999. Lord Lloyd stated in the judgment of Wells $v$ Wells ${ }^{15}$ :

I do not suggest that judges should be a slave to the tables. There may well be special factors in particular cases. But the tables should now be regarded as the starting-point, rather than a check. A judge should be slow to depart from the relevant actuarial multiplier on impressionistic grounds, or by reference to a "spread of multipliers in comparable cases" especially when the multipliers were fixed before actuarial tables were actually used.

Before Wells $v$ Wells, the rule was that the trier of fact determines the multiplier by reference to multipliers used in previous similar cases. This can be gleaned from the reported judgments. It appears as if it was permissible to refer to the Ogden Tables, but then only as a check on the preferred multiplier.

\subsection{English Rule 4: Assume 2.5\% per annum Real Discount Rate of Interest, when selecting the Multiplier}

Section 1 of the Damages Act 1996 allows for a discounting interest rate to be set for application by the courts. On 25 June 2001 the rate has been set at $2.5 \%$, and has not been changed since.

\section{Actuarial evidence in England}

\subsection{Ogden Tables}

The Actuarial Tables with explanatory notes for use in Personal Injury and Fatal Accident Cases are more commonly referred to as the Ogden Tables after the late Sir Michael Ogden QC, chairman of a Working Party of actuaries and lawyers. The tables show annuity factors (or 'multipliers' in legal

15 Wells $v$ Wells [1999] A.C. 345 at 379, [1998] 3 All ER 481. 
parlance) for a range of discounting rates of interest from $1.5 \%$ to $5 \%$. The tables have been expanded on in later editions and are extensively relied on by the English courts. Sir Michael placed a strong focus on ease of understanding of the tables. Thus

When it comes to the explanatory notes we must make sure that they are readily comprehensible. We must assume the most stupid circuit judge in the country and before him are the two most stupid advocates. All three of them must be able to understand what we are saying. ${ }^{16}$

\subsection{Actuarial Expert Testimony}

It is submitted that the rules that have been laid down in the manner of Sections 9 and 13 above lie at the root of the difference in treatment of the South African and English courts of actuarial expert testimony.

From section 12, expert opinion testimony is only admissible if it is sufficiently relevant. It is relevant if the expert is in a better position than the trier of fact to draw inferences from the established facts. In drawing inferences, the trier of fact must apply the rule of law.

The English trier of fact must determine the multiplicand. This he is well qualified to do, on the evidence before him. Next he must select the multiplier. This he can obtain from the Ogden Tables. Next he must apply his mind to any other subjective contingencies, and make the necessary adjustment to the multiplicand and the multiplier. Next he must multiply these two together. This is simple arithmetic.

In all these matters, it is doubtful that the actuary is sufficiently better qualified than the trier of fact to draw inferences. Thus, in the extreme, the court may rule the testimony of the actuary as inadmissible. Or the testimony may be admitted at additional cost and time in court, but the trier of fact may still decide to attach little weight to the opinion of the actuary. Should this happen, the actuary's testimony has provided little assistance to his client and the court.

Only in matters that the trier of fact is not sufficiently qualified in, will actuarial expert testimony be considered (Hodgkinson \& James, 2007:468).

\section{A possible weakness in the English axiomatic rules?}

Within the narrow environment set out in Section 6, and taking into account the rules in Section 13, it is clear from logical deduction that, in the English courts, a 'theorem of actuarial testimony' exists, which holds that 'actuarial testimony is [generally] inadmissible'17.

On the other hand it is suggested that most actuaries would be of the opinion that the above theorem is not necessarily true, and that many instances exist where actuarial testimony can lend appreciable assistance to the courts.

One way in which it can be shown that the theorem is not necessarily true, is to show that one of the rules in Section 13 is not necessarily true.

16 Sir Michael Ogden QC, on his explanatory notes to the First Edition of the Ogden Tables (1984).

17 Hodgkinson \& James (2007:467) notes that in practice a few exceptions exist, e.g. litigation in connection with pension fund values and insurance risks. 
In the view of the author, the one rule that is most doubtful is Rule 2: 'Use the multiplier-multiplicand method'.

Actuaries should recognise this rule as the simple actuarial principle of the valuation of an annuity. Ciecka (2008) records that these principles have been established by the work of the $17^{\text {th }}$ century Dutch mathematicians Jan (Johan) de Witt, Jan Hudde and Christiaan Huygens.

Since the time of the three mathematicians, major scientific advances regarding economic value have been made. Rubinstein (2006) provides a concise chronicle of some of these advances.

It is submitted that economic value is the modern tool to assist in determining the sum of money as envisaged by Lord Blackburn in section 13 above. The axiomatic use of a primitive actuarial tool such as the multiplier-multiplicand method that disregards some major developments in the theory of economic value over more than three centuries is surprising.

Within Section 6's narrow environment, English and South African courts would probably arrive at very similar answers for the loss, and so the English courts' exclusion of actuarial testimony under those circumstances seems reasonable.

However, based on the author's personal experience of South African legal process, and a reading of English law, even a small broadening of the environment can lead to a divergence in the answers.

A particularly simple example that might add clarity involves the relaxation of the 'no promotional prospects' assumption in Section 6.

The assumption is now made that the plaintiff is a young graduate at the start of his career. Amongst labour economists, as well as actuaries with some training in pension fund mathematics, it is common cause that his promotional prospects have a significant impact on the expected present value of his work-life earnings.

An assumption typically made by South African non-actuarial experts in the field of remuneration systems is that a new entrant to the job market can expect real promotional earnings growth of $5 \%$ per annum, until reaching a peak at the age of $40-45$.

Consider a scenario of (say) an individual aged 21 exactly with retirement age of 65 exactly. Using typical South African demographic and economic assumptions, the impact of the promotions can easily be quantified. In this case, relaxation of the 'no promotional prospects' assumption increases the value of work-life earnings by approximately $82 \% .{ }^{18}$

In this scenario, the English courts have to turn to the Ogden Tables. To evaluate the promotional aspects, the court has to turn to paragraph 23 of the Explanatory notes. This paragraph contains a brief but highly technical discussion on how to adjust the tables for promotional prospects. In this case, the trier of fact has to apply paragraph 23 and dissect the plaintiff's future lifetime earnings into at least 25 sections (more if a pension is involved). These sections run from age 21 to 22, age 22 to 23 , and so on up to age 44 to 45 and then finally age 45 to 65 . The trier of fact then has to

18 Assumptions appear in Appendix B. 
perform a calculation for each section in the manner set out in paragraph 23 , and then has to add the results for all the sections to arrive at a global amount.

For this exercise a spreadsheet and some actuarial ability would be helpful. It is submitted that it is doubtful that 'the most stupid circuit judge' together with 'the two most stupid advocates, ${ }^{19}$ (in Sir Michael Ogden's words) is likely to arrive at the correct answer.

Alternatively to paragraph 23 of the Explanatory notes, there is scope to allow for 'contingencies' which leaves a back door open for an implicit allowance for promotional prospects, by means of an adjustment by the trier of fact to the multiplier or multiplicand. This is quite subjective though and not subject to any scientific scrutiny.

South African courts, on the other hand, will allow explicitly for the possibility of real promotional earnings growth, on the strength of the testimony of experts in the field of employee remuneration systems. In practice, the court will turn to an actuary to assist the court in determining the likely numerical effect on the work life earnings, of real promotional earnings growth as identified and enumerated by other non-actuarial experts. South African courts are allowed this leeway, as they are simply following South African rules 1 and 2.

There is an additional benefit of the South African approach, which is also available to parties to a dispute in the English courts. The presentation of expert actuarial testimony allows counsel for the counterparty to cross-examine the witness and thus firmly establish the validity of the opinion. It also (in all probability) allows the counterparty to appoint a different actuary to present testimony in the matter. Thus, a peer review mechanism is introduced and the court has added comfort regarding the opinions of the respective experts.

English courts are also simply following their own 4 legal rules. Unfortunately, the outcomes may be significantly divergent for most but the simplest cases. It would appear that in this particular case the aims as stated by Lord Blackwell will not have been met.

This outcome is corroborated in part by an empirical study of Lewis et al. (2003) that compares awards for damages in Britain and the USA. They found strong evidence that British claimants are not fully compensated, in cases where the claimant has promotional prospects.

Matters can become much more complex, and South African triers of fact are prone in such cases to turn to the assistance of testimony of actuaries and other experts. Complications include:

- progressive taxation systems in conjunction with promotional increases producing crosscorrelation effects;

- A variety of possible life-time earnings paths both before and after the loss-causing incident, each with a particular probability associated with its realisation;

- periods of unemployment when the plaintiff has to undergo medical procedures as a result of the sequelae of the loss-causing incident (a medical specialist would normally be able to estimate the probability of a particular procedure, the age at which the procedure is likely to occur and the likely time off sick due to the procedure);

19 See footnote 16. 
- sick leave policy of employer;

- periods of unemployment due to family responsibility;

- different tax regimes, depending on the source of earnings;

- taxation of fringe benefits;

- different retirement ages before and after the loss-causing incident, and hence different pension levels;

- different tax regimes for pension benefits and earnings before retirement;

- part of pension taken as a lump sum;

- pension lump sum falling under a different tax regime as a regular pension; and

- non-integer ages and durations.

In South Africa, the trier of fact would usually consider actuarial expert testimony on the financial impact of these factors. It is not clear what the approach in England is, when dealing with these complications.

\section{Summary}

The legal procedural systems of South Africa and England are (as far as influence on the outcome of the deliberations) essentially the same, when applied to the assessment of future pecuniary damages.

However, and very surprisingly, South African courts embrace actuarial expert testimony whereas English courts do not, except in some narrowly defined circumstances.

This divergence arises out of a difference in the substantive law of damages as interpreted by the higher courts in the two jurisdictions.

This is also surprising, as South African quantum of damages is established primarily by consideration of rules and concepts found in English law.

In terms of substantive law, the South African courts' view is that no (or little) hard-and-fast rules can be made regarding the assessment of damages. Each case must be judged on its own merit. Within the adversarial system of adjudication, South African courts are in doubt as to which of the litigants to believe and are then more likely to turn to expert advice on matters in which the courts do not possess the necessary expertise.

However, the English approach has been to lay down simple rules of assessment that the courts can apply without deference to external expertise.

The doctrine of precedence enforces general compliance with these views.

English substantive law views loss as a simple multiplication exercise, with some judgment thrown in. The trier of fact is considered to be well equipped to perform this exercise.

South African substantive law views it as a solution to a complex stochastic processes problem, with some judgment thrown in. Once entering on more complex terrain such as stochastic processes, the courts are bound to call in the advice of experts, even more so in adversarial systems such as ours. 
For as long as the body of English substantive law views loss of earnings as a simple multiplication exercise, with a sprinkling of judgment added, it is the opinion of the author that it is not likely that the English courts will frequently turn to expert actuarial or similar testimony ${ }^{20}$.

It is submitted that the question of assessment of future pecuniary damages is essentially a stochastic processes question. In a simple case this may be reduced to a discrete process. A simple and easyto-use method such as the multiplier-multiplicand method will then produce an acceptable answer at low cost. In a more complex case, it becomes difficult (or impossible) to reduce the stochastic process to a simple discrete process. Assistance from actuaries and other experts is called for. Acceptance of this position is likely to enhance the relevance of actuarial and other expert testimony, as has been seen in South Africa.

Such a move is likely to enhance the status of science in the courtrooms, in general. A vast number of professionals and scientists in various fields are well equipped to assist the courts in their factfinding missions, if only they were permitted to do so. A reading of relevant South African case law shows that the courts rely extensively on expert testimony. From own experience, South African lawyers rely extensively on actuarial expert opinion in pre-trial negotiations. This assists in speedily narrowing down the points of disagreement within an adversarial legal system such as used both in England and South Africa.

Contrary to what might be thought, this system saves time and money as it gives the parties to the dispute a fairly accurate indication of what a likely reward of damages will be, while still treating the parties to the dispute fairly. Thus the risk of lengthy, costly trials to assess future pecuniary damages can be reduced.

It has been said that the English approach saves cost, and provides simplicity, certainty and consistency across cases.

There is a substantial risk, however, of an unfair award of damages when such a simplified approach is followed in a complex case involving large losses. In the opinion of the author, this risk outweighs the benefits of the other considerations, under such circumstances.

\section{Conclusion}

The quantification of future pecuniary damages arising out of loss of earnings by South African courts has its roots in concepts derived from English law.

However, over the past century or so there has been some divergence in approach. South African courts are reluctant to lie down fixed rules and readily rely on the testimony of experts. English courts, on the other hand, have laid down simplified rules to quantify future pecuniary damages. The intention is that the rules should be so simple that the court can perform any calculations that might be necessary without any external input.

It would appear that the English lawmakers are reluctant to take full account of advances made in actuarial and related sciences since the early days of actuarial science.

20 A reviewer of an earlier draft of this paper has indicated that the English courts are more likely to turn to economists and forensic accountants for advice, even though the advice is actuarial in nature. 
Over recent decades, actuarial science has shifted from a discrete approach in the direction of a stochastic approach. It is suggested that English lawmakers also consider a similar shift, even if only gradual.

Claims in England involving small amounts are likely to be settled fairly. As the extent of the loss increases, it becomes increasingly likely that the award for damages will be unfair to either the plaintiff or the defendant.

\section{Disclaimer}

This paper, although it covers material relating to the law, has been written by an actuary and not a lawyer. Its sole purpose is to stimulate debate within the actuarial profession. It does not purport to constitute legal advice. The author does not accept any responsibility for any reliance placed on it by third parties. Any reader who wishes to obtain legal advice or advice relating to matters where legal input may be of benefit, should seek such advice from a suitable qualified legal expert. It might be noted however that the author has given expert actuarial testimony regarding loss of earnings, both written and oral, on a large number of occasions.

\section{References}

Boberg, P.Q.B. (1984). The Law of Delict. Juta \& Co., Ltd, Cape Town Wetton Johannesburg.

Butt, Z., Haberman, S., Verrall, R. \& Wass, V. (2008). Calculating compensation for loss of future earnings: estimating and using work life expectancy. Journal of the Royal Statistical Society, 4, 763-805.

Burrows, A.S. (1987). Remedies for Torts and Breach of Contract. Butterworths, London.

Carstens, R.C. (2001). The social worker as expert witness in cases of child sexual abuse: a professional guideline. Unpublished Masters Dissertation, University of Pretoria.

Ciecka, J.E. (2008). The first mathematically correct life annuity. Journal of Legal Economics, 15(1), 59-63.

Daykin, C. (2009). Fair compensation needs actuaries. Journal of Personal Injury Law, 1, 48-65.

Erasmus, H.J. (1975). Aspects of the history of the South African law of damages. Tydskrif vir Hedendaagse Romeins-Hollandse Reg, 104-118, 268-283, 362-369.

Exall, G. (2004). Munkman on Damages for Personal Injuries and Death, Eleventh Edition. Lexis Nexis, UK.

Hahlo, H.R. \& Kahn, E. (1973). The South African Legal System and its Background. Juta \& Co., Limited, Cape Town.

Hodgkinson, T. \& James, M. (2007). Expert evidence: Law and Practice (Second Edition). Sweet \& Maxwell, London.

Holding, F.J. (1997). Essential Quantum Cases. Butterworths London, Edinburgh and Dublin.

Howroyd, R. \& Howroyd, F.J. (1958). The assessment of compensation for loss of support. South African Law Journal, LXXV(I), 65-83.

Koch, R.J. (1983). The actuary and damages for lost earnings. Transactions of The Actuarial Society Of South Africa, V(III), 78-118.

Koch, R.J. (1984). Damages for lost income. Juta \& Co, Ltd, Cape Town Wetton Johannesburg.

Koch, R.J. (1993). The Reduced Utility of a Life Plan as Basis for the Assessment of Damages for Personal Injury and Death. Doctorate dissertation, Faculty of Law, University of Stellenbosch. 
Lewis, R., McNabb, R., Robinson, H. \& Wass, V. (2003). Loss of earnings following personal injury: Do the courts adequately compensate injured parties? The Economic Journal, 113(November), F568-F584.

Meintjes-Van der Walt, L. (2001). A few plain rules? A comparative perspective on exclusionary rules of expert evidence in South Africa. Tydskrif vir Hedendaagse Romeins-Hollandse Reg, 64(Issue 2), 236-256.

Milburn-Pyle, P. \& van der Linde, J.H. (1974). The actuarial aspects of compensation for loss of support. Transactions of The Actuarial Society Of South Africa, II(II), 292-329.

Owen, R. \& Shier, P.S. (1986). The actuary in damages cases - expert witness or court astrologer? Journal of the Institute of Actuaries Students' Society, 29, 53-93.

Prevett, J.H. (1968). Actuarial assessment of damages. Journal of the Institute of Actuaries, 94, 293-343.

Prevett, J.H. (1972). Actuarial Assessment of Damages: The Thalidomide Case. The Modern Law Review, 35, No 2, 140-155 and 257-267.

Reyneke, M.F.B. (1976). Die elemente van die begrip skade. Tydskrif vir die Suid-Afrikaanse Reg, 26-58.

Rubinstein, M. (2006). A History of the Theory of Investments: my annotated bibliography. John Wiley \& Sons, Hoboken, N.J.

Schmidt, C.W.H. \& Rademeyer, H. (2000). Bewysreg. Lexis Nexis Butterworths, Durban.

Schmidt, C.W.H. \& Rademeyer, H. (2003). Law of Evidence. Lexis Nexis Butterworths, Durban.

Spengler, J.T. (1977). The Invisible Hand and Other Matters: Adam Smith on Human Capital. The American Economic Review, 67(No 1), 32-36.

Street, H. (1962). Principles of the Law of Damages. Sweet \& Maxwell Limited, London.

Van der Walt, J.C. \& Midgley, J.R. (2005). Principles of Delict. Lexis Nexis Butterworths, Durban. Visser, P.J. \& Potgieter, J.M. (2003a). Skadevergoedingsreg. Juta \& Kie, Bpk, Landsdowne.

Visser, P.J. \& Potgieter, J.M. (2003b). Visser and Potgieter's Law of Damages. Juta \& Co., Ltd, Landsdowne.

Zeffert, D.T., Paizes, A.P. \& Skeen, A. St Q. (2003). The South African Law of Evidence. Lexis Nexis Butterworths, Durban.

\section{Appendix A: Civil procedure in the High Court, as it would proceed in the particular circumstances of section 6}

1. Opening statements by counsel for the plaintiff and defendant, respectively.

2. Counsel for the plaintiff calls first witness to the witness stand to give verbal testimony.

3. Witness takes the oath.

4. Witness is questioned by counsel for the plaintiff (evidence-in-chief).

5. Counsel for the defendant cross-examines the witness.

6. Witness may be re-examined by counsel for the plaintiff.

7. Witness steps down from the witness stand.

8. Next witness is called and the process is repeated until all witnesses for the plaintiff have testified.

9. Counsel for the defendant calls first witness to the witness stand to give verbal testimony.

10. Witness takes the oath. 
11. Witness is questioned by counsel for the defendant (evidence-in-chief).

12. Counsel for the plaintiff cross-examines the witness.

13. Witness may be re-examined by counsel for the defendant.

14. Witness steps down from the witness stand.

15. Next witness is called and the process is repeated until all witnesses for the defendant have testified.

16. Closing statements by counsel for the plaintiff and defendant, respectively.

17. Trier of fact determines the award of damages.

\section{Appendix B: Assumptions used in calculating loss of earnings, Section 15}

Age at calculation date

Gender

Career peak

Earnings at calculation date

Income tax rates

Net discount rate

Real earnings growth rate until career peak

Mortality rates

\author{
21 years of age \\ Male \\ $42^{1 / 2}$ years of age \\ R150 000 p.a. \\ South African rates for individuals, 2010-2011 \\ $2 \frac{1}{2} \%$ p.a. \\ $5 \%$ p.a. \\ Table 2 from Quantum Yearbook of Koch, 2010
}

